\title{
Transparency for Enhancing Distinct Dimensions with Social Media Mediation on Citizens Trust in Ghana
}

\author{
Magdalene Z. A. Adams ${ }^{1 *}$ Ren Chong ${ }^{1}$ \\ ${ }^{1}$ School of Public Affairs, University of Science and Technology of China Hefei, Anhui, China. \\ *E-mail of the corresponding author: magmaame@yahoo.com
}

\begin{abstract}
Transparency in government has led to much research and has aroused interest in quality and content improvement. Building on the attention already received, this study contributes to the continual debate about government transparency and proposes six parameters that government information should address to enhance trust among citizens. The study's empirical analysis validated the proposed model for accuracy and examined the possible impact of government transparency enhancement in public accountability, service delivery, urban and rural development, and government effectiveness, as well as how social media use can mediate to promote rapid information access to citizens and interested stakeholders. Findings on the analysis indicated a significant impact of government information on enhancing the proposed dimensions and the use of social media for communication and improvement in all aspects proposed. The analysis shows that social media is an essential and appropriate strategy to communicate and seek ideas from citizens to enhance services that influence trust in the government.
\end{abstract}

Keywords: Government transparency; Citizens trust; Social media use; Services delivery.

DOI: $10.7176 / \mathrm{PPAR} / 9-5-08$

Publication date:May $31^{\text {st }} 2019$

\section{Introduction}

Citizens have the right to petition the authorities and have their voices heard when citizens need clarifications in the performances and functions of their public officials (Carbone, 2019). In an approach, citizens lack of trust for government and institutions in the public sector requires a robust intervention to combat the challenge of citizens mistrust. Equitable distribution of resources to citizens and society for successful policymaking has necessitated openness in the services of public officials. Citizens expectations of government and politicians are that they should always have an approach that conveys openness and allows for scrutiny, working for the interest of the public while promoting socio-economic development and growth (Wang, 2016). Citizens also expect specific areas that affect their existence addressed appropriately, with the disclosure of timely information from the operations that require public attention to enable provisions for uncertainties to adjust living conditions accordingly. One way, to begin with, is mainly, the demands of most citizens in Ghana to an increased quest for the enhancement of transparency in government. However, the issue is not just about enhancing transparency in government, but also, citizens expect the information communicated to improve distinct areas that provide safety and assurance for development and in public services.

This concern further requires establishing tasks that relate to how citizens perceive of the government and public organizations recognising areas to carry out functions that embrace openness, trust, and innovative ideas for improvement in the public sectors the way they are entrusted. As a result, transparency enhancement in distinct areas is essential as was pointed out by Flyverbom (2015), as transparency contributes to finding ideal solutions to a wide range of societal problems and positive developments in governance. Studies like Cucciniello and Nasi (2014), identified a framework aiming to monitor transparency in the extent of information disclosure based on dimensions as institutional, political, financial, and service delivery. This study explores whether proposed factors of public accountability, services delivery, urban and rural development, and government effectiveness will influence the level of government information and responsibility to citizens and society. Utilizing a survey approach concerning Ghana, and statistical inferences, our study developed and tested a proposed model of transparency information enhancing distinct recommended dimensions. This study endorses strengthening the mode of communication through different available social media platforms to reach a majority of the citizens and further recommends intensifying government information on public accountability, services delivery, urban and rural development, and government effectiveness.

\section{Theoretical Background}

Recurrent concerns about questions raised regarding government performances and information to citizens have prompted inquiry in the general roles of most governments worldwide. The urgency of transparency 
enhancement worldwide is evident in the global recommendations in the $2030 \mathrm{UN}$ agenda, which lists government transparency as a priority for encouraging sustainable development. The agenda is towards developing peaceful, just, inclusive societies for all, and building an effective, accountable, and inclusive institutions to encourage participation and improvement in serving citizens and society (Steiner, 2018). As is evident in developing and developed countries, transparency gives citizens the right to freedom of information (FOI) with no restrictions to information disclosures (Michener and Worthy, 2018). However, efforts to improve anticipation in government performance and information to citizens and potential users of information have proven somewhat futile in many countries since many of the critical issues expected of government information to address are missing.

The magnitude of the insufficient and disappointing provision of reliable information and dependable services to citizens has raised demands requiring a boost in government information as a platform to address issues in the society (Kim, 2010). As a result, public sectors are requested to solicit citizens engagement and participation in government processes to envisage the intentions of the users and potential users of government information and whether the information entails the required details and needs of the users. This occurs because the interests of public officials are different from that of the citizens as such; the actions of the public officials must be supported with evidence of their activities. Transparency in government massive attentiveness links partially to citizens increased quest for diversity in governmental transparency information and need to improve reforms in varied sectors to restrain corruption and agitate improvement in services and services provisions to the citizens (Bauhr and Grimes, 2014). Increasing transparency information would be effectual when government information strengthens distinct areas and influences positively on the development of the country and also reduce corruption to improve operations of public sectors to provide services satisfaction to citizens (Lindstedt and Naurin, 2010).

Taking another approach, determinants of government transparency and trust may vary and not necessarily the same for every country and political culture; determinants also depends on the policy and design of each country (De Fine Licht, 2014). However, in general, government information to citizens is required to tackle sectors that need attention for refinement but have been overlooked drawing citizens dissatisfaction and urge for the potential approach of government through transparency enhancement (Kosack and Fung, 2014). This concern intensifies public value and instigates the reductions of redundancy in performances and implementations of the public sectors. In line with Grimmelikhuijsen et al. (2013) and Worthy (2015), sharing government information should focus on comprehensiveness and how the information presented can benefit citizens in diverse ways in planning and managing their place in society.

\section{Social media use context in Ghana}

Social media use has become pleasing and an acceptable norm in society, serving as an approach for governments, journalists, organizations, and individuals to have more significant avenues for engaging each other in a network of communication, interaction, collaboration and feedback share for enhancements in the provision of services to each other (Kent). The growth in social media use in Africa has hugely affected Ghanaians because of the country's investment in internet access (Atiso and Kammer, 2018) which shows the level of the citizens' quest for technology acceptance (Davis, 1989). The use of social media platforms as a means of awareness creation in Ghana has witnessed an upsurge; this media contributes to services to individuals involved with education, politics, business, health, and governance.

Besides its contribution to networking and keeping people informed on issues relevant to democratic values and aspirations, this type of media also plays a prominent role in Ghana's mediascape broadcasting to individuals (Avle, 2011). Journalists have developed a growing trend to adopt these media as professional tools for information dissemination and citizen engagement in discussion of national and social issues, emergencies, and finding possible solutions to issues affecting citizens' life. Like those in other developed and developing countries in the world, users of social media in Ghana can become addicted to social media platforms. Social platforms available in Ghana for government and other public agencies to adopt for daily communication and to deliver value propositions to citizens include examples of Facebook, Instagram, Twitter, Linked In, Flickr, Snapchat, YouTube, Google+, and Yahoo. 
Though social media platforms serve an integral part of media content creation and information dissemination in the development of Ghana, it poses threats to Ghanaian youth and individuals, for instance, cyber fraud, exposure to excessive contents, inappropriate languages and gestures (Atiso and Kammer, 2018). Literature related to our hypotheses for the proposed model represented in Figure 1 is explained further in the next section.

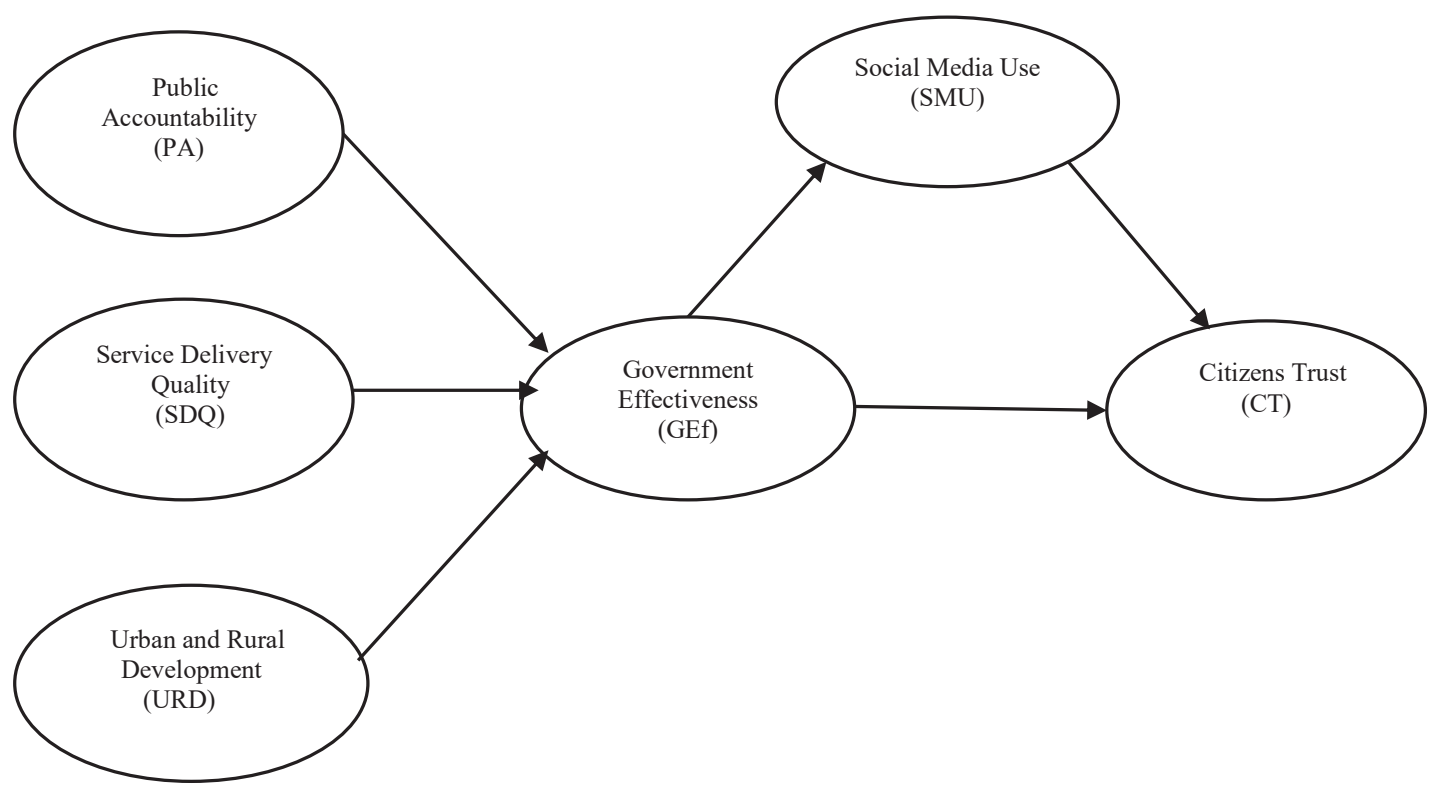

Figure 1. Proposed model

\section{Hypothesis Development}

Public Accountability (PA)

Government performances to citizens should not be behind closed doors but open to the public whereby interested users of information can widely access for diverse interests and judgement. Transparent governments and public agencies regularly inform, educate, and involve citizens in processes that involve public attention towards the stages of development of the country (Bovens, 2007). Constant information to citizens aid in strengthening public policies for growth and effectiveness in the public sectors (Santiso, 2001). Accounting to citizens communicates information that previously was kept private: disclosures of the government and government officials' intention on public services, their records of contracts intended to benefit citizens, and records of campaign finances. Awareness about the information communicated makes it easier to combat political corruption and provide a platform for collaborating with citizens on strengthening public services and the relationship between the government and the citizens. (Porumbescu, 2017, Schillemans, 2016).

Intensifying public accountability to citizens increases the rate of correcting possible errors and adding new ideas to promote development in services to citizens. As a result, the information presented by public officials to citizens is to be clear and concise on the country's budget, financial statements and other initiations carried out by the public sectors to benefit citizens. However, in this study accountability evaluates the effectiveness of the country's public institutions as well as political trust and the extent to which government programs and institutional systems are contributing to developing and promoting the general citizen welfare.

Hypothesis 1: Public accountability, will enhance effectiveness in the government and public sectors' to serve citizens.

\section{Service Delivery Quality (SDQ)}

The citizens' expectations about the quality of services provided by public officials and agencies play a critical role in shaping citizens views regarding services delivery and services effectiveness. In general, standard services to citizens are water and electricity, public health care and education, garbage collection and waste management, environmental services, fire-fighting, emergency services, traffic regulation, urban planning, regulatory enforcement, and local public works and housing (Akinloye Akinboade et al., 2012). In the willingness to provide quality services to citizens, the services to implement should lead to the creation of value 
for citizens and capable of influencing trust in the government and the public services. It is crucial that government performance through public officials and public sectors benefit citizens in its entirety. However, reforms that enable effective services delivery to meet societies expectations is obligatory (Puppim de Oliveira et al., 2015).

Factors to consider when talking about delivering quality services to citizens include the extent to which most citizens can be covered and how effectively the services can impact, without discrimination and the overall standards of the people (Christensen and Lægreid, 2005). Factors contributing to deficiencies in services delivery to citizens identified by Akinloye Akinboade et al. (2012), includes financial mismanagement, maladministration, corruption, nepotism, lack of effective leadership in the municipality, and lack of communication with communities, all of which are evident in most developing and developed countries. Services to citizens become valuable with provisions made for potential hindrances and possibly co-produce for enhancement in services to service users and society. Service delivery proposed for the study assesses the degree of satisfaction in efforts of the government and public officials in handling of services to citizens and the public.

Hypothesis 2: Citizens level of satisfaction in services delivered will increase creativity in public sectors to perform effectively and promote government effectiveness and trust.

\section{Urban and Rural Development (URD)}

Most citizens in Ghana are eager to witness and discover information concerned with improvements and enhancement in urban as well as in rural areas. Information delivery and policies implemented by the government and public agencies is envisaged in this area to emphasize the importance of the development of rural areas, and its significant impact on rural economies to rise the rural living standards. However, the anticipation is that government information helps to assess the choice of urban-rural development programmes and how they can be extended in rural social issues. Information to citizens on rural matters should be capable of stimulating and exploiting individual creative skills to help in rural change and evaluate the extent to which rural development can improve the attractiveness into urban (Grimmelikhuijsen and Feeney, 2017).

The dispensing of government information has the power to positively affect citizens' attitudes (Piotrowski et al., 2017) and promote a conducive atmosphere for sharing feedback. Therefore, the engagement and participation of citizens in areas, the source of disclosure, and the type of public works in developing areas like in Ghana are essential. This aids in making informed decisions, corrections, refinements, and improvements for enhancing development, boosting enterprises to improve the living conditions of citizens.

Hypothesis 3: Frequency of information on urban and rural development, solicit the citizens' interest in capacity building to impact national development and government effectiveness.

\section{Government Effectiveness (GEf)}

The worldwide governance indicators (WGI) projects six dimensions of good governance in developed and developing countries. The aspects include voice and accountability, political stability and absence of violence, government effectiveness, regulatory quality, the rule of law, and the control of corruption. Effectiveness necessitates citizens perceptions of the level of quality services, the performance of civil services, and its independence from political pressures. As such, the credibility of commitment by government and public agencies to the quality of policy formulation and implementation enhances trust among citizens (Kaufmann et al., 2009). Government efficiency improves when information to citizens, as well as associated policy-making, formulation, and implementation, support and enhance democracy (Magalhães, 2014).

Government efforts to improve effectiveness, reduce corruption, and increase regulatory quality expand the rate of innovation in government and other public sectors to advance development in the various areas (Oluwatobi et al., 2015). Effectiveness in government assesses how the government manages and communicates about information and policy issues that improve the efficiency of distinct areas and the public sector. These measures initiate management of the budget, public debt and the efficiency of public expenditures in Ghana

Hypothesis 4: Government information in a more transparent effort enhance effectiveness in distinct areas and citizens trust in the government.

\section{Mediation of Social Media Use (SMU)}

The use of social media platforms in government functions has been deemed a success for improving communication, citizen participation, transparency, and the transfer of best practices among government agencies (Picazo-Vela et al., 2012). The government's use of media platforms as additional channels for dissemination of information improves communication with citizens and engages citizens in plans and decisions essential in government (Song and Lee, 2016). The concept of citizens omnipresence has dramatically influenced the government's use of media platforms to serve a wide range of the public at an equal rate of information dissemination and acquisition (Zavattaro and Sementelli, 2014). The use of social media platforms extends 
citizen perspectives on a wide range of information, policies, and possible gaps that need to be addressed, thus creating awareness and consciousness of the performance of government and public agencies.

Using social media is a strategy that creates conveniences for various sectors to disclose information about their execution and performance, but understanding the benefits while avoiding the risks of social media is essential (Kim et al., 2015). A lack of understanding of modern technologies and platforms harm their initiation and efficiency in providing the desired advantages. Thus, awareness of the adverse effects of social media is essential, rather than only the benefits social media offers. These challenges related to privacy, security, data management, accessibility, social inclusion, governance, and other information policy issues should be approached carefully (Bertot et al., 2012) because social media empowers citizens to pay attention of information on government agency sites and to read officials' blogs regularly.

Hypothesis 5: Social media use presents government activities and functions inaccessible way, enlightening citizens and creating interactive approaches to enhance development.

Citizens Trust in government (CT)

Trust in government is enhanced with endeavours by the government to bring practical transparency actions to citizens. Government actions (efforts) to serve the nation need a platform to communicate past, present, and future directions, and what has been done to address citizens' problems in sustaining a livelihood. Most government officials and agencies act in secrecy, hiding their deeds and feeding the public wrong perceptions; this duplicity affects the smooth running of government, and in turn, citizens lose trust in the functions of the government. Most citizens demand transparency in the government, because of their need to learn more about actions and plans for the citizens.

It is therefore vital for the government to initiate trust-building actions with citizens because the persistent decline in trust in government, leads to bias in the performance of public institutions and detracts the government's ability to govern well (Porumbescu, 2018). Institutions must be encouraged to reveal relevant information about their performances, actions, and decision processes which covers general citizens welfare and procedures to execute operations (Curtin and Meijer, 2006). Allowing external actors (citizens) to monitor and assess internal workings and performance in the government fosters transparency (Grimmelikhuijsen et al., 2013) and enable government officials, citizens, and all stakeholders to make informed and precise judgements.

Hypothesis 6: Evaluation of the operations and effectiveness in government information induce citizens trust.

\section{Methodology}

Empirical settings and data collection process

To validate this study's hypothesis, the study conducted a survey to collect data from 2018 , November $15^{\text {th }}$ to December $30^{\text {th }}$. In all stages, respondents were informed of the research purpose before they filled out the questionnaire to assist the study objectives. Initially, the study conducted two pilot tests on respondents which were essential for identifying uncertainties that hinder the validity of the research statistical results and analysis (De Vaus, 2013). Testing initial samples $(n=8)$ on potential respondents generated general assumptions about the population at large. Secondly, the pilot test $(n=20)$ was conducted to detect potential problems and gaps in the research design to ensure the study used reliable and valid measurement instruments. The survey was sent out to 604 various eligible prospective contacts after the purpose of the pilot test was achieved. Survey distribution was through Emails, WeChat, WhatsApp, and Facebook and followed up by a reminder to encourage responses from people who had not completed the survey or assisted by sending the survey out to at least one contact.

This study obtained 505 survey responses, of which 414 answers were found valid and reliable for advancing the study. Respondents represented a demographic description of gender, age, work status, and living area as presented in Table 1. The response rate was valid to further the research analysis (Hair et al., 1998) as the maximum likelihood estimation needs at least $n \geq 400$ samples (Schermelleh-Engel et al., 2003) to estimate model parameters. 
Table 1. Demographic description of data samples

\begin{tabular}{|c|c|c|}
\hline Option & $\begin{array}{l}\text { Frequency (f) } \\
(n=414)\end{array}$ & Percentage (\%) \\
\hline \multicolumn{3}{|l|}{ Gender } \\
\hline Male & 240 & 58.0 \\
\hline Female & 174 & 42.0 \\
\hline \multicolumn{3}{|l|}{ Age } \\
\hline \multirow{2}{*}{$\begin{array}{l}21-30 \\
31-40\end{array}$} & 126 & 30.4 \\
\hline & 174 & 42.0 \\
\hline $41-50$ & 57 & 13.8 \\
\hline $51-60$ & 41 & 9.9 \\
\hline $60+$ & 16 & 3.9 \\
\hline \multicolumn{3}{|l|}{ Work status } \\
\hline $\begin{array}{l}\text { Government employed } \\
\text { Private sector employed }\end{array}$ & 99 & 23.9 \\
\hline \multirow{2}{*}{$\begin{array}{l}\text { Private sector employed } \\
\text { Self-employed }\end{array}$} & 110 & 26.6 \\
\hline & 79 & 19.1 \\
\hline Unemployed & 25 & 6.0 \\
\hline \multirow{2}{*}{$\begin{array}{l}\text { Retired employee } \\
\text { Student }\end{array}$} & 21 & 5.1 \\
\hline & 80 & 19.3 \\
\hline \multicolumn{3}{|l|}{ Living area } \\
\hline \multirow{2}{*}{$\begin{array}{l}\text { Urban } \\
\text { Rural }\end{array}$} & 211 & 51.0 \\
\hline & 203 & 49.0 \\
\hline
\end{tabular}

Measurement Assessment

The measurement instruments were primarily adapted from published works, with slight modifications of words and structure to suit the current study. The survey items to measure constructs shown in Table 2, proposed items based on public accountability and urban and rural development items from Piotrowski and Van Ryzin (2007). Services delivery quality items from Zhao and $\mathrm{Hu}$ (2017), government effectiveness items from the world bank governance indicators index by Kaufmann et al. (2011), social media use items from Song and Lee (2016), and citizens trust items from Welch et al. (2004).

The study employed 5-point Likert scales for all six variables measuring different responses with ' 1 ' indicating extremely dissatisfied, ' 3 ' neutral, and ' 5 ' as extremely dissatisfied (PA, SDQ, URD) or ' 1 ' strongly disagree, ' 3 ' as neutral and ' 5 ' indicating strongly agree (GEf, SMU, and CT). 
Table 2. List of measurement items

\begin{tabular}{|c|c|c|c|}
\hline Constructs & Measurement Items & M & SD \\
\hline \multirow{4}{*}{$\begin{array}{l}\text { Public Accountability } \\
\text { (PA) }\end{array}$} & 1. Information on country's budgets and financial statements & 3.60 & 0.732 \\
\hline & 2. Disclosures on records of government officials' expense accounts & 3.52 & 0.755 \\
\hline & 3. Government records and contracts including who was granted the contract(s) & 3.43 & 0.678 \\
\hline & 4. Campaign finance records & 3.40 & 0.708 \\
\hline \multirow{7}{*}{$\begin{array}{l}\text { Service } \\
\text { Quality } \\
\text { (SDQ) }\end{array}$} & 1. Public health systems (Clinics and Hospitals) & 3.42 & 0.816 \\
\hline & 2. Job creation & 3.51 & 0.846 \\
\hline & 3. Water and Electricity distribution & 3.52 & 0.834 \\
\hline & 4. Firefighting and other emergency services & 3.39 & 0.824 \\
\hline & 5. Road construction and maintenance & 3.33 & 0.901 \\
\hline & 6. Crime reduction & 3.40 & 0.813 \\
\hline & $\begin{array}{l}\text { 7. Environmental services, waste management, streetlight maintenance, and traffic } \\
\text { regulation }\end{array}$ & 3.49 & 0.777 \\
\hline \multirow{3}{*}{$\begin{array}{l}\text { Urban and Rural } \\
\text { Development } \\
\text { (URD) }\end{array}$} & 1. Engagement and participation of areas & 3.39 & 0.719 \\
\hline & 2. Source of disclosure used for areas & 3.36 & 0.742 \\
\hline & 3. Local public works in developing areas (rural development agendas) & 3.37 & 0.862 \\
\hline \multirow{4}{*}{$\begin{array}{l}\text { Government } \\
\text { Effectiveness } \\
\text { (GEf) }\end{array}$} & 1. Policies to improve efficiency of the public sector & 3.58 & 0.853 \\
\hline & 2. $\quad$ Budget management & 3.57 & 0.890 \\
\hline & 3. Management of public debt & 3.50 & 0.896 \\
\hline & 4. Efficiency of public expenditures (revenue mobilization) & 3.50 & 0.884 \\
\hline \multirow{5}{*}{$\begin{array}{l}\text { Social Media Use } \\
\text { (SMU) }\end{array}$} & 1. A fun of government agency or official on their social media site & 3.70 & 0.786 \\
\hline & 2. Do u read a government officials' blog & 3.63 & 0.793 \\
\hline & $\begin{array}{l}\text { 3. Ever joined a government agency or official conversation on social platforms } \\
\text { (Twitter, Facebook etc.) }\end{array}$ & 3.71 & 0.823 \\
\hline & $\begin{array}{l}\text { 4. Social media use in government help citizens to be more informed about } \\
\text { government doings }\end{array}$ & 3.71 & 0.807 \\
\hline & $\begin{array}{l}\text { 5. Social media use in government make government agencies and officials more } \\
\text { accessible }\end{array}$ & 3.71 & 0.732 \\
\hline \multirow{4}{*}{$\begin{array}{l}\text { Citizens Trust } \\
\text { (CT) }\end{array}$} & 1. Would trust government and officials to do right things much of the times & 3.52 & 0.755 \\
\hline & 2. Government officials wastes lots of money we pay for taxes & 3.68 & 0.678 \\
\hline & $\begin{array}{l}\text { 3. Government is run by few big interests seeking officials who look out for } \\
\text { themselves }\end{array}$ & 3.64 & 0.708 \\
\hline & $\begin{array}{l}\text { 4. Always agree with officials' running the government by their actions and } \\
\text { performances }\end{array}$ & 3.46 & 0.816 \\
\hline
\end{tabular}

Exploratory factor analysis (EFA) measured all variables through maximum likelihood extraction with the rotation method, using Promax with Kaiser Normalization (Table 3). Cronbach's Alpha for the study estimated a threshold value of $\alpha>0.70$ (Gliem and Gliem, 2003). 


\section{Measurement Validation}

Structural equation modeling (SEM) and confirmatory factor analysis (CFA) reduced the observed variables to smaller latent variable numbers for straightforward inferences. This study used the SEM technique with LISREL 8.80 to measure the most common model indices to test for model fit considering chi-square $\left(x^{2}\right)$, degrees of freedom $(d f)$, chi-square per degree of freedom $\left(x^{2} / d f\right)$, root mean square error of approximation (RMSEA), adjusted goodness-of-fit index (AGFI), normed fit index (NFI), comparative fit index (CFI), and goodness of fit index (GFI). According to statistical inferences by researchers, the validity of the empirical model is assumed if the data fit meets following thresholds: $x^{2}$ meets a threshold of 5.0 (Barrett, 2007), $x^{2} / d f$ is $\leq 3$ or $\leq 5$ (Kline, 2005), GFI $\geq 0.95$ and AGFI $\geq 0.95$ (Shevlin and Miles, 1998), RMSEA $\geq 0.05$ or $\leq 0.08$ (MacCallum et al., 1996), CFI $\geq 0.95$ (Hu and Bentler, 1999), IFI > 0.90 (McDonald and Marsh, 1990), and NFI $\geq 0.95$ (Hu and Bentler, 1999).

Composite reliability (CR) has the acceptable thresholds of $\geq 0.7$ (Hair et al., 2010) and $\geq 0.5$ for average variance extracted (AVE) (Fornell and Larcker, 1981); Table 3, presents the analysed results. This study also determined the discriminant validity by using Fornell and Larcker (1981) test that proposed validity in constructs if AVE squared root exceeds the correlation among constructs. As shown in Table 4, the data indicates no correlations exceeding the square root of AVE, which shows good discriminate validity in the proposed constructs. The proposed constructs measured structural equations, error variance, and $\mathrm{R}^{2}$ as shown below:

$$
\begin{gathered}
G E f=0.23 * P A+0.22 * S D Q+0.24 * U R D \\
\text { Error var. }=0.34 \\
R 2=0.40 \\
\text { SMU }=0.68 * \text { GEf } \\
\text { Error var. }=0.51 \\
R 2=0.34 \\
\text { CT } 2.24 * \text { GEf }+0.40 * S M U \\
\text { Error var. }=0.40 \\
R 2=0.36
\end{gathered}
$$

\section{Results and Findings}

Indexes calculated for measurement and structural model (Table 5) showed statistical goodness of fit in measurement and validity. However, a Sobel test conducted showed significant mediation of $p<0.01$ and test of 8.77. Confirming acceptable levels of the goodness of fit and validity convergence, this study tested linkages and relationships given in our hypotheses to establish statistical inferences on constructs (Klayman and Ha, 1987). The results obtained based on results from using IBM SPSS 23 through regression analysis indicates positive significant relationships for the six proposed hypotheses illustrated in Figure 2. 
The relationship of public accountability and government effectiveness is positive $(\beta=0.416, p<0.001)$, as are the relationships of service delivery quality and government effectiveness $(\beta=0.449, p<0.001)$, urban and rural development with government effectiveness $(\beta=0.458, p<0.001)$. Government effectiveness is positively associated respectively with social media use and citizens trust in government $(\beta=0.510, p<0.001, \beta=0.415, p<0.001)$, and the use of social media

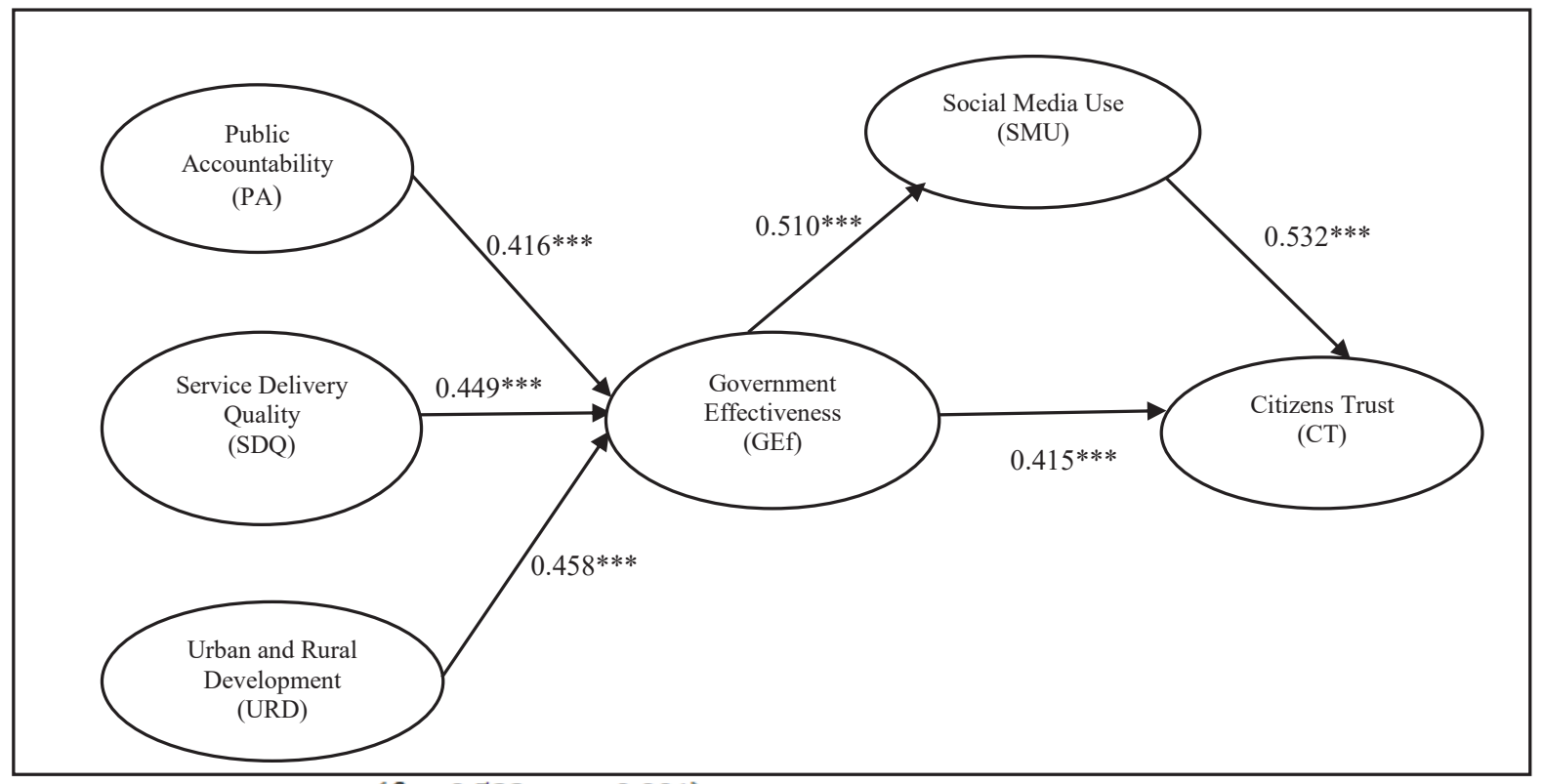

relates to citizens trust $(\beta=0.532, p<0.001)$.

Figure 2. Validated model results

The descriptive statistics represented in Table 3 shows the factor loadings, CRs, and AVEs of the six constructs are higher than threshold values of 0.70 , and 0.5 showing good convergent validity.

Table 3. Descriptive statistics of measurement variables

\begin{tabular}{|c|c|c|c|c|c|}
\hline \multirow{2}{*}{$\begin{array}{r}\text { Constructs } \\
\text { Public Accountability }\end{array}$} & \multicolumn{2}{|c|}{ Factor Loadings } & \multirow{2}{*}{$\begin{array}{c}\text { Cronbach's Alpha } \\
0.870 \\
\end{array}$} & \multirow{2}{*}{$\frac{\mathbf{C R}}{0.86}$} & \multirow{2}{*}{$\frac{\mathbf{A V E}}{0.61}$} \\
\hline & PA 1 & 0.813 & & & \\
\hline & PA 2 & 0.765 & & & \\
\hline & PA 3 & 0.785 & & & \\
\hline & PA 4 & 0.768 & & & \\
\hline \multirow{7}{*}{$\begin{array}{l}\text { Service Delivery Quality } \\
\text { (SDQ) }\end{array}$} & SDQ 1 & 0.811 & 0.926 & 0.93 & 0.64 \\
\hline & SDQ 2 & 0.765 & & & \\
\hline & SDQ 3 & 0.803 & & & \\
\hline & SDQ 4 & 0.775 & & & \\
\hline & SDQ 5 & 0.814 & & & \\
\hline & SDQ 6 & 0.819 & & & \\
\hline & SDQ 7 & 0.810 & & & \\
\hline \multirow{3}{*}{$\begin{array}{l}\text { Urban and Rural Development } \\
\text { (URD) }\end{array}$} & URD 1 & 0.853 & 0.899 & 0.89 & 0.73 \\
\hline & URD 2 & 0.886 & & & \\
\hline & URD 3 & 0.823 & & & \\
\hline \multirow{4}{*}{$\begin{array}{l}\text { Government Effectiveness } \\
\text { (GEf) }\end{array}$} & GEf 1 & 0.775 & 0.903 & 0.90 & 0.69 \\
\hline & GEf 2 & 0.832 & & & \\
\hline & GEf 3 & 0.808 & & & \\
\hline & GEf 4 & 0.902 & & & \\
\hline
\end{tabular}




\begin{tabular}{|l|c|c|c|c|c|}
\hline \multicolumn{1}{|c|}{ Constructs } & \multicolumn{2}{|c|}{ Factor Loadings } & Cronbach's Alpha & CR & AVE \\
\hline \multirow{4}{*}{$\begin{array}{l}\text { Social Media Use } \\
\text { SMU) }\end{array}$} & SMU 1 & 0.846 & 0.932 & 0.92 & 0.71 \\
\hline & SMU 2 & 0.803 & & & \\
\hline & SMU 3 & 0.891 & & & \\
\hline & SMU 4 & 0.827 & & & \\
\cline { 2 - 7 } & SMU 5 & 0.830 & & & \\
\hline \multirow{4}{*}{$\begin{array}{l}\text { Citizens Trust } \\
\text { (CT) }\end{array}$} & CT 1 & 0.854 & 0.913 & 0.91 & 0.71 \\
\hline & CT 2 & 0.910 & & & \\
\hline & CT 3 & 0.807 & & & \\
\cline { 2 - 7 } & CT 4 & 0.804 & & & \\
\hline
\end{tabular}

Based on path coefficients and t-value statistics measurement, the model has significant positive acceptable relationships (Table 6).

Table 4. Correlation matrix and square root of AVE

\begin{tabular}{|c|l|c|c|c|c|c|c|}
\hline Factor & \multicolumn{1}{|c|}{ Variables } & $\mathbf{1}$ & $\mathbf{2}$ & $\mathbf{3}$ & $\mathbf{4}$ & $\mathbf{5}$ & $\mathbf{6}$ \\
\hline $\mathbf{1}$ & Service delivery quality & $\mathbf{0 . 7 8 1}$ & & & & & \\
\hline $\mathbf{2}$ & Social media use & $0.538^{* *}$ & $\mathbf{0 . 8 0 0}$ & & & & \\
\hline $\mathbf{3}$ & Citizens trust & $0.453 * *$ & $0.556^{* *}$ & $\mathbf{0 . 8 5 4}$ & & & \\
\hline $\mathbf{4}$ & Government effectiveness & $0.483 * *$ & $0.532 * *$ & $0.443 * *$ & $\mathbf{0 . 8 3 1}$ & & \\
\hline $\mathbf{5}$ & Public accountability and rural & $0.491 * *$ & $0.518^{* *}$ & $0.432^{* *}$ & $0.454 * *$ & $\mathbf{0 . 8 4 3}$ & \\
\hline $\mathbf{6}$ & $\begin{array}{l}\text { Urban } \\
\text { development }\end{array}$ & $0.558^{* *}$ & $0.469 * *$ & $0.493 * *$ & $0.433^{* *}$ & $\mathbf{0 . 8 4 3}$ \\
\hline
\end{tabular}

** Bivariate levels and bold numbers show AVE in square root.

Correlation is significant with $\mathrm{p}<0.01$.

Table 5. Goodness of Fit statistics measures for model

\begin{tabular}{|c|l|l|l|l|l|l|l|l|l|}
\hline Model Indices & $\boldsymbol{\chi}^{\mathbf{2}}$ & $\boldsymbol{d f}$ & $\boldsymbol{\chi}^{\mathbf{2}} / \boldsymbol{d f}$ & $\boldsymbol{R M S E A}$ & $\boldsymbol{N F I}$ & $\boldsymbol{C F I}$ & $\boldsymbol{I F I}$ & $\boldsymbol{G F I}$ & $\boldsymbol{A G F I}$ \\
\hline 1. Measurement Model & & & & & & & & & \\
Model Score & 509.96 & 309 & 1.650 & 0.040 & 0.98 & 0.99 & 0.99 & 0.92 & 0.90 \\
\hline 2. Structural Model & & & & & & & & & \\
Model Score & 620.51 & 315 & 1.970 & 0.048 & 0.97 & 0.99 & 0.99 & 0.90 & 0.88 \\
\hline
\end{tabular}

Table 6. Results of Structural Relationships of Constructs in Lisrel (Path Analysis)

\begin{tabular}{|c|c|c|c|c|}
\hline Hypothesis & Path Relationship & Estimates & Standardized & T-Values \\
\hline H1 & PA $\rightarrow$ GEf & 0.23 & 0.23 & $4.11^{* * *}$ \\
\hline H2 & SDQ $\rightarrow$ GEf & 0.22 & 0.24 & $4.15^{* * *}$ \\
\hline H3 & URD $\rightarrow$ GEf & 0.24 & 0.30 & $5.23 * * *$ \\
\hline H4 & GEf $\rightarrow$ SMU & 0.68 & 0.58 & $11.12^{* * *}$ \\
\hline H5 & SMU $\rightarrow$ CT & 0.40 & 0.44 & $7.50 * * *$ \\
\hline H6 & GEf $\rightarrow$ CT & 0.24 & 0.23 & $3.92 * * *$ \\
\hline
\end{tabular}

$* * * p<0.001$ level. 


\section{Discussion}

The significant impact on PA, SDQ, URD, GEf, SMU, and CT constructs demonstrate the importance of enhancing every aspect through government communication. Research studies like Kim et al. (2015), examined the role of developing public trust using social media (Twitter) to intensify public awareness and consciousness of government action and inaction. This study takes the view that the trust of citizens on the government also depends on other forms of social media platforms available to citizens for accessing all dimensions of government information. The relationship established between citizens and the government through various available media platforms enables citizens to collaborate with online information and share feedback. However, the considerable variations that exist in information sharing offer essential insights and strategic implications for rectification of faults.

The study observation is that public accountability has the positive effect of exposing unfruitful contracts and dealings in government and public sector performances. This exposure means that the public can debate services pros and cons to the citizens before acceptance and implementation. Continuous accountability to citizens can serve as a check to monitor public officials and agencies' daily performances of services rendered to citizens. Efforts to scrutinize public officials is also a strategic way to enhance the government's plans and services to implement and to detect geographical areas that are served well while also identifying ones lacking services; this knowledge should help adjust policies to give equal access to benefits for all citizens. However, to provide quality services to citizens, it is necessary to consider efforts that create value for the public and provide new and innovative insights, competencies, and solidarity among citizens. The quality of services supplied to citizens will favourably influence trust and pave the way for the government to improve its performance and the effectiveness of the public sector.

Thus, we also expect that government information disclosures to Ghanaians will improve, as well as rural integrity, changing the quality and status of rural life as the development of rural areas is a high priority in many countries. Therefore, the engagement, participation, and inclusion of all citizens in creating avenues that best initiate progress in such areas are essential. Improving rural lives and the rural economy is critical for rural transformation, and approaching citizens through communication and information sharing assists in dealing with specific problems. This approach also helps formulate strategies, procedures, and techniques for addressing outstanding issues.

In another step, government efforts in communicating issues that require attention are necessary, as is evident in Figure 2, which reports high correlations of $\beta$ values for GEf, SMU, and CT. This sudy note that both positive comments and criticisms in information share are useful for improvement in services and governance. Dissemination of government information is an important key for contributing to structural reforms to motivate government and other public sectors in their operations. This dissemination should also reduce redundancy in poorly functioning sections due to timely information reaching citizens. Thus, social media use by governments with the aid of journalists enhance efficiency and effectiveness in government and public services and to bridge gaps that may exist in communication.

On this regard, this study further concludes that transparency in government and public sectors cannot only contribute to the development of Ghana, but government information on the improvement of different dimensions that promote good governance is essential. Social media platforms can supplement government information dissemination and provide the opportunity for direct interaction, and feedback between government officials and Ghanaian citizens as wider audience relies much on government information.

\section{Conclusions}

This study contributes to the value of government information and social media for communication to citizens by all dimensions. Thus, the recommendation is that government and public officials should always be obligated to ensure the provision and sharing of general information with citizens to promote government functionality. This study has found that citizens trust relies not only on transparent government but also on the effective functioning of other essential dimensions of society, as reflected in the variables proposed for the study in Ghana. This knowledge about different aspects can aid government and public officials and agencies to explore, consider, and accept varied opinions from citizens to help amend and improve various services to the public.

One final point: public officials must always publicise the "true picture of the economy" to communicate precisely with citizens. Secrecy fosters misrepresentation and uncertainty, but public awareness of developments is a necessity for a progressive country. Thus, future research should investigate ways that governments can use social media effectively to motivate their citizens' input on government effectiveness. Trust between the government and citizens depend on increased collaboration to promote enhancement in areas that will foster 
development. Thus, government information to citizens that addresses barriers affecting citizens livelihood and communication induce citizens trust.

\section{References}

Akinloye Akinboade, O., Chanceline Kinfack, E. \& Putuma Mokwena, M., 2012, "An analysis of citizen satisfaction with public service delivery in the Sedibeng district municipality of South Africa", International Journal of Social Economics 39, 182-199.

Atiso, K. \& Kammer, J., 2018, "User Beware: Determining Vulnerability in Social Media Platforms for Users in Ghana", Library Philosophy and Practice, 1.

Avle, S., 2011, "Global flows, media and developing democracies: The Ghanaian case", Journal of African Media Studies 3, 7-23.

Barrett, P., 2007, "Structural equation modelling: Adjudging model fit", Personality and Individual differences $42,815-824$.

Bauhr, M. \& Grimes, M., 2014, "Indignation or resignation: The implications of transparency for societal accountability", Governance 27, 291-320.

Bertot, J. C., Jaeger, P. T. \& Hansen, D., 2012, "The impact of polices on government social media usage: Issues, challenges, and recommendations", Government information quarterly 29, 30-40.

Bovens, M., 2007, "Analysing and assessing accountability: A conceptual framework 1", European law journal $13,447-468$

Carbone, C. A., 2019, "Lobbying in developing countries: The P eruvian case", Journal of Public Affairs, e1901.

Christensen, T. \& Lægreid, P., 2005, "Trust in government: The relative importance of service satisfaction, political factors, and demography", Public Performance \& Management Review 28, 487-511.

Cucciniello, M. \& Nasi, G., 2014, "Transparency for trust in government: How effective is formal transparency?", International Journal of Public Administration 37, 911-921.

Curtin, D. \& Meijer, A. J., 2006, "Does transparency strengthen legitimacy?", Information Polity 11, 109-122.

Davis, F. D., 1989, "Perceived usefulness, perceived ease of use, and user acceptance of information technology", MIS quarterly, 319-340.

De Fine Licht, J., 2014, "Policy area as a potential moderator of transparency effects: An experiment", Public Administration Review 74, 361-371.

De Vaus, D. 2013. Surveys in social research, Routledge.

Flyverbom, M., 2015, "Sunlight in cyberspace? On transparency as a form of ordering", European Journal of Social Theory 18, 168-184.

Fornell, C. \& Larcker, D. F., 1981, "Evaluating structural equation models with unobservable variables and measurement error", Journal of marketing research 18, 39-50.

Gliem, J. A. \& Gliem, R. R. Calculating, interpreting, and reporting Cronbach's alpha reliability coefficient for Likert-type scales. 2003. Midwest Research-to-Practice Conference in Adult, Continuing, and Community Education.

Grimmelikhuijsen, S., Porumbescu, G., Hong, B. \& Im, T., 2013, "The effect of transparency on trust in government: A cross - national comparative experiment", Public Administration Review 73, 575-586.

Grimmelikhuijsen, S. G. \& Feeney, M. K., 2017, "Developing and testing an integrative framework for open government adoption in local governments", Public Administration Review 77, 579-590.

Hair, J., Black, W., Babin, B. \& Anderson, R., 2010, "Multivariate data analysis Upper Saddle River: Pearson Prentice Hall.[Links]".

Hair, J. F., Anderson, R. E., Tatham, R. L. \& William, C. 1998. Black (1998), Multivariate data analysis. Upper Saddle River, NJ: Prentice Hall.

Hu, L. T. \& Bentler, P. M., 1999, "Cutoff criteria for fit indexes in covariance structure analysis: Conventional criteria versus new alternatives", Structural equation modeling: a multidisciplinary journal 6, 1-55.

Kaufmann, D., Kraay, A. \& Mastruzzi, M. 2009. Governance matters VIII: Aggregate and individual governance indicators 1996-2008, The World Bank. 
Kaufmann, D., Kraay, A. \& Mastruzzi, M., 2011, "The worldwide governance indicators: methodology and analytical issues", Hague Journal on the Rule of Law 3, 220-246.

Kent, M. L. 2015. Social media circa 2035: Directions in social media theory. Taylor \& Francis.

Kim, S., 2010, "Public trust in government in Japan and South Korea: Does the rise of critical citizens matter?", Public Administration Review 70, 801-810.

Kim, S. K., Park, M. J. \& Rho, J. J., 2015, "Effect of the Government's Use of Social Media on the Reliability of the Government: Focus on Twitter", Public Management Review 17, 328-355.

Klayman, J. \& Ha, Y.-W., 1987, "Confirmation, disconfirmation, and information in hypothesis testing", Psychological review 94, 211.

Kline, R. B., 2005, "Principles and practice of structural equation modeling".

Kosack, S. \& Fung, A., 2014, "Does transparency improve governance?", Annual review of political science 17, 65-87.

Lindstedt, C. \& Naurin, D., 2010, "Transparency is not enough: Making transparency effective in reducing corruption", International Political Science Review 31, 301-322.

Maccallum, R. C., Browne, M. W. \& Sugawara, H. M., 1996, "Power analysis and determination of sample size for covariance structure modeling", Psychological methods 1, 130.

Magalhães, P. C., 2014, "Government effectiveness and support for democracy", European Journal of Political Research 53, 77-97.

Mcdonald, R. P. \& Marsh, H. W., 1990, "Choosing a multivariate model: Noncentrality and goodness of fit", Psychological bulletin 107, 247.

Michener, G. \& Worthy, B., 2018, "The information-gathering matrix: A framework for conceptualizing the use of freedom of information laws", Administration \& Society 50, 476-500.

Oluwatobi, S., Efobi, U., Olurinola, I. \& Alege, P., 2015, "Innovation in A frica: Why Institutions Matter", South African Journal of Economics 83, 390-410.

Picazo-Vela, S., Gutiérrez-Martínez, I. \& Luna-Reyes, L. F., 2012, "Understanding risks, benefits, and strategic alternatives of social media applications in the public sector", Government information quarterly 29, 504511.

Piotrowski, S., Grimmelikhuijsen, S. \& Deat, F., 2017, "Numbers over narratives? How government message strategies affect citizens' attitudes", Public Performance \& Management Review, 1-24.

Piotrowski, S. J. \& Van Ryzin, G. G., 2007, "Citizen attitudes toward transparency in local government", The American Review of Public Administration 37, 306-323.

Porumbescu, G., 2017, "Linking transparency to trust in government and voice", The American Review of Public Administration 47, 520-537.

Porumbescu, G. A., 2018, "A slow and steady approach to building trust in government", Journal of Public Administration Research and Theory.

Puppim De Oliveira, J. A., Jing, Y. \& Collins, P., 2015, "Public administration for development: trends and the way forward", Public Administration and Development 35, 65-72.

Santiso, C., 2001, "Good governance and aid effectiveness: The World Bank and conditionality", The Georgetown public policy review 7, 1-22.

Schermelleh-Engel, K., Moosbrugger, H. \& Müller, H., 2003, "Evaluating the fit of structural equation models: Tests of significance and descriptive goodness-of-fit measures", Methods of psychological research online 8, 23-74.

Schillemans, T., 2016, "Calibrating Public Sector Accountability: Translating experimental findings to public sector accountability", Public Management Review 18, 1400-1420.

Shevlin, M. \& Miles, J. N., 1998, "Effects of sample size, model specification and factor loadings on the GFI in confirmatory factor analysis", Personality and Individual differences 25, 85-90.

Song, C. \& Lee, J., 2016, "Citizens' use of social media in government, perceived transparency, and trust in government", Public Performance \& Management Review 39, 430-453.

Steiner, A., 2018, "The extraordinary opportunity of the 2030 Agenda for Sustainable Development", The European Journal of Development Research 30, 163-165. 
Wang, C. H., 2016, "Government Performance, Corruption, and Political Trust in East Asia", Social Science Quarterly 97, 211-231.

Welch, E. W., Hinnant, C. C. \& Moon, M. J., 2004, "Linking citizen satisfaction with e-government and trust in government", Journal of Public Administration Research and Theory 15, 371-391.

Worthy, B., 2015, "The impact of open data in the UK: Complex, unpredictable, and political", Public Administration 93, 788-805.

Zavattaro, S. M. \& Sementelli, A. J., 2014, "A critical examination of social media adoption in government: Introducing omnipresence", Government information quarterly 31, 257-264.

Zhao, D. \& Hu, W., 2017, "Determinants of public trust in government: Empirical evidence from urban China", International Review of Administrative Sciences 83, 358-377.

\section{Appendix}

Data and analysis related to this study: http://dx.doi.org/10.17632/6d5s $7 \mathrm{bpwfr} .1$ 